\title{
Low-Dose Tissue Plasminogen Activator and Standard-Dose Tissue Plasminogen Activator in Acute Ischemic Stroke in Asian Populations: A Review
}

\author{
Siva Seeta Ramaiah ${ }^{\mathrm{a}}$ Bernard Yan ${ }^{\mathrm{a}, \mathrm{b}}$ \\ ${ }^{a}$ Melbourne Brain Centre, Royal Melbourne Hospital, Melbourne, Vic., and ${ }^{b}$ Neurointervention Service, \\ Department of Radiology, Royal Melbourne Hospital (RMH), Parkville, Vic., Australia
}

\section{Key Words}

Low-dose tissue plasminogen activator · Standard-dose tissue plasminogen activator - Thrombolysis · Acute ischemic stroke $\cdot$ Asian population

\begin{abstract}
Background: The burden of stroke is becoming an important issue in Asian countries, where half of the world's population lives. In Western populations, standard-dose intravenous tissue plasminogen activator (tPA) at a dose of $0.9 \mathrm{mg} /$ $\mathrm{kg}$ administered up to $4.5 \mathrm{~h}$ following acute ischaemic stroke has been shown to improve clinical outcomes. However, the dosage of tPA in Asian populations varies, partly influenced by treatment costs in developing countries and the perceived racial differences in treatment response. Furthermore, no randomized controlled trial of intravenous tPA thrombolysis has been carried out in Asia with the exceptions of observational and multicentre registries in Japan. Summary of the Review: This review aims to examine the current use of low-dose tPA in Asian populations with particular emphasis on its clinical benefits. Historically, the findings of 2-chain tPA (duteplase) trials in the early 1990s were the basis of low-dose tPA in Japan, and standard-dose tPA was chosen taking into account a pilot dose escalation study.
\end{abstract}

Most of the trials incorporating low-dose tPA suggested that low-dose tPA has clinical efficacy comparable with the standard dose and that it is associated with a lower incidence of symptomatic haemorrhage. It follows that consensus regarding the dosage of tPA is wanting. Conclusions: Standard-dose tPA would be a reasonable choice in Asian populations until the results are available from randomized controlled studies comparing low-dose with standard-dose tPA.

(c) 2013 S. Karger AG, Basel

\section{Introduction}

Stroke is one of the leading causes of disability and death in developed and developing countries [1,2]. Intravenous tissue plasminogen activator ( $\mathrm{tPA} ; 0.9 \mathrm{mg} / \mathrm{kg}$ ) remains the only proven effective drug treatment for acute ischaemic stroke (AIS) since its approval by the US FDA in 1996 [3]. Although 1 in 17 patients in the National Institute of Neurological Disorders and Stroke trial (NINDS) tPA cohort had haemorrhagic transformation, the trial showed that patients treated with tPA were at least 30\% more likely to have an excellent outcome at 3 months $[3,4]$. The more recent European Cooperative Acute Stroke Study III (ECASS III) trial provided addi-

\section{KARGER}

(c) 2013 S. Karger AG, Basel

$1015-9770 / 13 / 0363-0161 \$ 38.00 / 0$

E-Mail karger@karger.com

www.karger.com/ced
Assoc. Prof. Bernard Yan

Royal Melbourne Hospital Grattan Street

Parkville, VIC 3050 (Australia)

E-Mail Bernard.yan@mh.org.au 
tional evidence that a treatment benefit of intravenous tPA still exists up to $4.5 \mathrm{~h}$ following the onset of stroke [5].

In Asia, thrombolytic treatment has not been widely applied despite the 3 million deaths annually secondary to AIS occurring in relatively younger age groups (35-64 years old) compared to Western populations $[6,7]$. One of the reasons of the lower rates of tPA utilization is tPArelated intracerebral haemorrhage which is due to racial differences in blood coagulation and fibrinolysis [8].

Although the recommended dose of intravenous tPA according to the NINDS [3], the Alteplase Thrombolysis for Acute Non-Interventional Therapy in Ischemic Stroke (ATLANTIS) [9], and the ECASS III trials [5] is $0.9 \mathrm{mg} /$ $\mathrm{kg}$ body weight (maximum $90 \mathrm{mg}$ ), $0.6 \mathrm{mg} / \mathrm{kg}$ is the only approved dosage in Japan since 2005 for the treatment of patients within $3 \mathrm{~h}$ of onset based on the results of the Japan Alteplase Clinical Trial (J-ACT), which suggested clinical benefits [10]. Subsequent studies, J-ACT2 and Japan post-Marketing Alteplase Registration Study (JMARS), also demonstrated a favourable outcome in both efficacy and safety with a lower dose of alteplase $(0.6 \mathrm{mg} /$ $\mathrm{kg}$ ) in the Japanese population $[11,12]$. In the absence of randomized evidence and given the uncertainty regarding the dosages and safety of thrombolysis in Asia (outside the Japanese population), we conducted a review comparing low-dose and standard-dose tPA.

\section{Historical Reasons for Standard-Dose tPA}

Two pilot dose escalation studies by Brott et al. [13] and Haley et al. [14] were the basis for standard-dose tPA. In the first pilot study, the investigators tested doses of $0.35(\mathrm{n}=6), 0.60(\mathrm{n}=12), 0.85(\mathrm{n}=30), 0.95(\mathrm{n}=25)$ and $1.08(\mathrm{n}=1) \mathrm{mg} / \mathrm{kg}$ within $90 \mathrm{~min}$ of symptom onset on patients aged $18-80$ years with acute cerebral ischaemia leading to a serious measurable deficit [13]. The study demonstrated a higher proportion of major neurological improvement at $24 \mathrm{~h}$ in the $0.85 \mathrm{mg} / \mathrm{kg}$ tier (55\%) compared with the $0.6 \mathrm{mg} / \mathrm{kg}$ tier (33\%), with no symptomatic intracranial haemorrhage (SICH) when a dose of $\leq 0.85 \mathrm{mg} / \mathrm{kg}$ was used [13]. In the second study, Haley et al. [14] tested three doses of tPA in patients presenting within 90-180 min after symptom onset [0.6 $(\mathrm{n}=8), 0.85$ $(\mathrm{n}=6)$ and $0.95(\mathrm{n}=6) \mathrm{mg} / \mathrm{kg}]$ and observed SICH in the two higher doses with a risk of SICH approximating 17\% in doses of $\geq 0.85 \mathrm{mg} / \mathrm{kg}$. Different efficacy at lower doses of tPA in these pilot trials was never tested and a proposed trial to compare 0.6 with $0.9 \mathrm{mg} / \mathrm{kg}$ of tPA in the mid1990s was not approved for funding by the NINDS [15].

\section{Historical Reasons for Low-Dose tPA}

In Japan, three randomized double-blind trials of duteplase were conducted 20 years ago in embolic stroke patients treated within $6 \mathrm{~h}$ of onset [16-18]. Duteplase is a 2-chain form of tPA glycoprotein of 527 amino acids produced by gene recombinant technology from a culture of Chinese hamster ovary cells with very similar properties (biologically and pharmacologically) to alteplase [16]. Based on the angiographic recanalization rate, 20 million international units (MIU) of duteplase proved to be superior to placebo [17]. Twenty MIU (equal to $0.33 \mathrm{MIU} /$ $\mathrm{kg}$ or $0.6 \mathrm{mg} / \mathrm{kg}$ of tPA) were comparable to $30 \mathrm{MIU}$ regarding both angiographic recanalization and clinical improvement in this dose comparison study [18]. However, SICH occurred in $13.8 \%$ of patients who had received 30 MIU [18]. From the financial standpoint, low-dose tPA (i.e. which generally requires the use of a single 50 -mg vial of Actilyse ${ }^{\circledR}$, Boehringer Ingelheim) is the preferred option for patients in China and Taiwan who cannot afford the full dose (i.e. 2 vials).

\section{Arguments for Low-Dose tPA}

Based on the three randomized trials on duteplase, the J-ACT [10] was undertaken with an alteplase dose of 0.6 $\mathrm{mg} / \mathrm{kg}$, which is equivalent to $20 \mathrm{MIU}$ per person or 0.33 MIU/kg at a mean body weight of $60 \mathrm{~kg}$ [10]. The J-ACT is a prospective cohort study (table 1) that evaluated 103 patients within $3 \mathrm{~h}$ of AIS and showed equivalent clinical outcomes but a reduced risk of SICH compared to expected rates from the standard $0.9 \mathrm{mg} / \mathrm{kg}$ dose [10]. $37 \%$ of patients in the J-ACT had a modified Rankin Scale (mRS) score of $0-1$ at 3 months and a $5.8 \%$ rate of SICH [10].

Mori et al. [11], in a magnetic resonance angiography (MRA)-based prospective cohort study (J-ACT2), enrolled 58 ischaemic stroke patients within $3 \mathrm{~h}$ of onset who had MRA-documented middle cerebral artery occlusion [11]. The dose of alteplase was similar to the JACT study $(0.6 \mathrm{mg} / \mathrm{kg})$ and the vascular outcome was evaluated by MRA at 6 and $24 \mathrm{~h}$ after symptom onset based on the modified Mori scale. Recanalization was noted on MRA in $51.7 \%$ of patients at $6 \mathrm{~h}$ and in $69.0 \%$ of patients at $24 \mathrm{~h}$ after symptom onset. A favourable clinical outcome (mRS score of $0-1$ at 3 months after onset) was achieved in $46.6 \%$ of patients with none having SICH [11]. The J-MARS [12] was conducted for 2 years enrolling 7,492 patients in 942 centres to investigate whether thrombolysis with $0.6 \mathrm{mg} / \mathrm{kg}$ intravenous alteplase could 
Table 1. Trials incorporating low-dose tPA

\begin{tabular}{|c|c|c|c|c|c|c|c|c|c|}
\hline Publication & $\begin{array}{l}\text { Patients, } \\
\text { n }\end{array}$ & $\begin{array}{l}\text { tPA dose, } \\
\mathrm{mg} / \mathrm{kg}\end{array}$ & $\mathrm{n}$ & $\%$ & $95 \%$ CI & $\mathrm{n}$ & $\%$ & $95 \%$ CI & $\begin{array}{l}\text { Death within } \\
3 \text { months, } n\end{array}$ \\
\hline $\begin{array}{l}\text { Yamaguchi et al. [10], } \\
2006 \\
(\mathrm{~J}-\mathrm{ACT})\end{array}$ & 103 & 0.6 & $38 / 103$ & 36.9 & $28.0-46.5$ & $6 / 103$ & 5.8 & $2.4-11.7$ & $10 / 103(9.7)$ \\
\hline $\begin{array}{l}\text { Toyoda et al. [34], } \\
2009 \\
\text { (SAMURAI register) }\end{array}$ & 600 & 0.6 & $199 / 600$ & 33.2 & $29.5-37.0$ & $23 / 600$ & 3.8 & $2.6-5.7$ & $43 / 600(7.2)$ \\
\hline $\begin{array}{l}\text { Sharma et al. [25], } \\
2010\end{array}$ & $48 / 130$ & 0.6 & $17 / 48$ & 35.4 & $22.9-49.6$ & $7 / 48$ & 14.5 & $6.6-26.7$ & $5 / 48(10)$ \\
\hline $\begin{array}{l}\text { Mori et al. [11], } \\
2010 \text { (J-ACT II) }\end{array}$ & 58 & 0.6 & $27 / 58$ & 46.6 & $34.0-59.4$ & $0 / 58$ & 0 & $0-5.0$ & $1 / 58(1.7)$ \\
\hline $\begin{array}{l}\text { Nakagawara et al. [12], } \\
2010 \text { (J-MARS) }\end{array}$ & 7,492 & 0.6 & $1,631 / 4,944$ & 33.1 & $31.8-34.4$ & $259 / 7,492$ & 3.5 & $2.5-6.2$ & $\begin{array}{l}985 / 7,492 \\
(13.1)\end{array}$ \\
\hline $\begin{array}{l}\text { Nguyen et al. [21], } \\
2010\end{array}$ & $48 / 121$ & $\begin{array}{l}0.62 \\
(0.6-0.86)\end{array}$ & $27 / 48$ & 56.3 & $42.1-69.7$ & $1 / 48$ & 2.1 & $0.1-9.8$ & $1 / 48(2.1)$ \\
\hline $\begin{array}{l}\text { Zhou et al. [23], } \\
2010\end{array}$ & $54 / 105$ & $0.6-0.8$ & $20 / 54$ & 37 & $25.0-50.4$ & $2 / 54$ & 3.9 & $0.6-11.7$ & 9/54 (17) \\
\hline $\begin{array}{l}\text { Chen et al. [22], } \\
2012\end{array}$ & 105 & $\begin{array}{l}0.7 \\
(0.66-0.74)\end{array}$ & $39 / 95$ & $41.1^{\mathrm{c}}$ & NA & $5 / 105$ & 4.8 & NA & 8/105 (7.6) \\
\hline
\end{tabular}

Figures in parentheses are ranges or percentages. NA $=$ Not available.

${ }^{a}$ Defined by an mRS score of $0-1$ unless otherwise specified. ${ }^{b}$ Defined as intracranial haemorrhage within $36 \mathrm{~h}$ resulting in neurological deterioration (increase in NIHSS score by $\geq 4$ points) unless otherwise specified. ${ }^{c}$ Favourable clinical outcome assessed in patients with a prestroke $\mathrm{mRS}$ score of $\leq 1$.

be safe and effective in routine clinical practice for Japanese patients [12]. The study demonstrated 33\% favourable outcome in the efficacy analysis of 4,944 patients. In the safety analysis of 7,492 patients, the incidence of SICH was $3.5 \%$ within $36 \mathrm{~h}$ and the overall mortality rate was $13.1 \%$ [12]. The results of the J-MARS were comparable with a similar post-marketing study in the European Union, the Safe Implementation of Thrombolysis in Stroke Monitoring Study (SITS-MOST), which used an alteplase dose of $0.9 \mathrm{mg} / \mathrm{kg}$ [19].

Studies outside Japan also demonstrated a favourable outcome in both efficacy and safety analyses with a lower dose of alteplase [20-22]. In the Vietnamese population, Nguyen et al. [21] conducted a prospective study in 48 patients choosing a similar treatment protocol to that of the NINDS trial but with a lower dose of tPA (range, 0.6$0.86 \mathrm{mg} / \mathrm{kg}$ ). Compared with the standard dose, patients treated with low-dose intravenous tPA were more likely to achieve functional independence at 3 months $(34.2 \%$ with standard-dose vs. $56.3 \%$ with low-dose tPA; $\mathrm{p}=$ 0.01 ) with only 1 patient having SICH in the low-dose group compared to 4 patients in the standard-dose alteplase group [21]. In the Chinese population, Chao et al. [20] demonstrated in the Taiwan Thrombolytic Therapy 
for Acute Ischemic Stroke (TTT-AIS) study that the standard dose of $0.9 \mathrm{mg} / \mathrm{kg}$ alteplase might not be optimal for treating aged Chinese patients. In their study, the authors recruited 241 patients with $\mathrm{PA}$ indication and exclusion criteria similar to the SITS-MOST study [23], of whom 116 and 125 received a low dose $(0.72 \pm 0.07)$ and a standard dose $(0.9 \mathrm{mg} / \mathrm{kg})$, respectively. The lower-dose group demonstrated a higher percentage of functional independence (mRS score $0-1$ ) of $41.4 \%$ in all age groups, and in those aged $\geq 70$ years, the rate in the low-dose group was 53.6 versus $32.6 \%$ in the standard-dose group [20]. The investigators found that patients who were given the standard dose had twice the risk of having SICH (8.0 vs. $2.6 \%$, respectively) and of dying within 3 months (12.8 vs. $6.9 \%)$ compared with those on the lower dose [20]. In another Taiwan-based study, Chen et al. [22] recruited 261 patients in a retrospective, two-centre study, of whom 105 and 156 received a low dose $(0.7 \mathrm{mg} / \mathrm{kg})$ and a standard dose $(0.9 \mathrm{mg} / \mathrm{kg})$, respectively. The study demonstrated no difference between the standard-dose and the low-dose groups regarding a favourable outcome in patients with an mRS score of $\leq 1$ at 3 months (38.4 and $41.1 \%$, respectively; $\mathrm{p}=0.676$ ), and the occurrence of SICH was non-significantly lower in the standard-dose group than in the low-dose group (2.6 vs. $4.8 \%$, respectively; $\mathrm{p}=0.34$ ) [22].

To sum up, the studies in this section included prospective cohort studies and post-marketing observational studies. There were no randomized controlled studies to investigate the safety profile of low-dose tPA. However, there was a suggestion that low-dose tPA was associated with a lower incidence of SICH.

\section{Arguments for Standard-Dose tPA in Asian Patients}

A meta-analysis of about 3,700 patients included in many large randomized trials in North America and Europe examining intravenous tPA administered to AIS patients up to $4.5 \mathrm{~h}$ after symptom onset provides very strong evidence of the overall net benefit of the standarddose regimen $(0.9 \mathrm{mg} / \mathrm{kg})$ [24]. Although there has never been any randomized clinical trial testing the efficacy of standard-dose tPA therapy in Asian AIS patients, a few retrospective studies have shown its feasibility and safety [25-27]. In a study conducted in Singapore, Sharma et al. [25] reported their experience with AIS patients given low-dose intravenous tPA (maximum $50 \mathrm{mg}$ ) from 2000 to 2006 and later switched to standard-dose intravenous tPA (maximum $90 \mathrm{mg}$ ) in a retrospective cohort design involving 48 and 82 patients, respectively. $59 \%$ of the patients achieved functional independence (mRS score $0-1$ ) at 3 months with standard-dose tPA, compared with 35\% in the low-dose group $(\mathrm{p}=0.011)$ and SICH occurred more frequently with the low dose (14.5\%) than with the standard dose $(1.2 \% ; p=0.004)$ [25]. In a Thai population study, Suwanwela et al. [27] prospectively recruited 34 patients following the inclusion and exclusion criteria of the NINDS tPA trial, who were subjected to standarddose intravenous tPA $(0.9 \mathrm{mg} / \mathrm{kg}) .47 \%$ of the patients achieved a favourable clinical outcome (mRS score $0-1$ ) with a $5.9 \%$ rate of SICH [27]. In a Han Chinese population retrospective study, Zhou et al. [23] recruited 105 patients of all AIS patients treated with tPA within $4.5 \mathrm{~h}$ of onset of whom 51 patients received a standard dose of intravenous $\mathrm{tPA}(0.9 \mathrm{mg} / \mathrm{kg})$ and the remaining 23 and 31 patients received $0.6-0.7$ and $0.8 \mathrm{mg} / \mathrm{kg}$, respectively [23]. $51.1 \%$ achieved a favourable clinical outcome (mRS score $0-1)$ at 3 months in the standard group, compared with $38.7 \%$ patients in the $0.8 \mathrm{mg} / \mathrm{kg}$ group and $34.8 \%$ patients in the $0.6-0.7 \mathrm{mg} / \mathrm{kg}$ group with a similar rate of SICH (3.9\% according to ECASS III criteria) in both groups [23].

To sum up, the studies in this section included several case series in Asian populations, but the number of patients remained small. There was a trend towards less favourable clinical recovery in patients who received lowdose tPA.

\section{Why the Difference between Asians and Caucasians?}

Iso et al. [35] demonstrated a higher amount of measured antigens of tPA and plasminogen activator inhibitor 1 in Caucasian than in Japanese populations. Other major differences between both populations were the absence of factor $\mathrm{V}$ Leiden and prothrombin mutations in the Japanese population, and the rarity of polymorphism of a platelet integrin, the glycoprotein IIIa 33Leu/Pro [28]. Apart from potential differences in the haemostatic profile of Japanese patients, there are well-documented differences in the genetic polymorphism pattern in Caucasians. Recently, in a genome-wide association study of four population-based cohorts, 19,602 white persons were recruited by the Cohorts for Heart and Aging Research in Genomic Epidemiology (CHARGE) consortium which reported two single nucleotide polymorphisms, rs11833579 and rs12425791, to be significantly associated with the incidence of ischaemic stroke [29]. However, another study in the Japanese population by 
Matsushita et al. [30] identified rs12425791 to be significantly associated with the incidence of atherothrombotic stroke whereas rs11833579 was not. The authors postulated that the failure of replication of an association between ischaemic stroke and rs11833579 was due to the weak linkage disequilibrium between a true causative variant in the Japanese population and that particular single nucleotide polymorphism [30]. Furthermore, it is well described that Asian patients are at a higher risk of intracranial atherosclerosis with reported rates of $33-50 \%$ in China, $47 \%$ in Thailand, $56.3 \%$ in Korea and $47.9 \%$ in Singapore [31]. This has also led to the speculation that there may be differing dosing requirements in Asia.

\section{Future Studies}

A large-scale randomized clinical trial is needed, though challenging, to show the real difference in the effects of the two doses of tPA in AIS patients. A realistic solution would be a non-inferiority study to determine the optimum dose of tPA. Perhaps the recently launched trial Enhanced Control of Hypertension and Thrombolysis in Stroke Disease (ENCHANTED) would settle the controversy of tPA dose in AIS. ENCHANTED being a quasi-factorial randomized controlled study was designed to address 4 key questions in which 2 pertinent issues are whether low-dose tPA $(0.6 \mathrm{mg} / \mathrm{kg})$ is truly equivalent in efficacy, or even safer (low risk of SICH), to the standard dose $(0.9 \mathrm{mg} / \mathrm{kg})$, not just in Asians with AIS but also in other population groups around the world. Two other objectives of ENCHANTED are the effect of intensive blood pressure lowering on outcomes and the risk of SICH.

\section{Conclusions}

There are wide variations in the dosing of intravenous tPA for AIS with the tendency to use lower dosages in Asian populations. The low-dose intravenous tPA is an attractive option due to reduced costs and is proposed as a solution to overcome the underutilization of thrombolysis in developing countries [32]. However, given that lack of level 1 evidence for low-dose tPA, we would recommend the application of standard-dose tPA in Asian populations until the results are available from randomized controlled studies comparing low-dose with standard-dose tPA.

\section{References}

1 Donnan G, Fisher M, Macleod M, Davis S: Stroke. Lancet 2008;371:1612-1623.

-2 Murray CJ, Lopez AD: Mortality by cause for eight regions of the world: global burden of disease study. Lancet 1997;349:1269-1276.

-3 The National Institute of Neurological Disorders and Stroke rt-PA Stroke Study Group. Tissue plasminogen activator for acute ischemic stroke. N Engl J Med 1995;333:15811587.

4 Saver JL: Number needed to treat estimates incorporating effects over the entire range of clinical outcomes: novel derivation method and application to thrombolytic therapy for acute stroke. Arch Neurol 2004;61:10661070.

5 Hacke W, Kaste M, Bluhmki E, et al: Thrombolysis with alteplase 3 to 4.5 hours after acute ischemic stroke. N Engl J Med 2008;359: 1317-1329.

6 Poungvarin N: Stroke in the developing world. Lancet 1998;352(suppl III):19-22.

7 Feigin VL: Stroke epidemiology in the developing world. Lancet 2005;365:2160-2161.

-8 Ueshima S, Matsuo O: The differences in thrombolytic effects of administrated rt-PA between Japanese and Caucasians. Thromb Haemost 2002;87:544-546.
-9 Clark WM, Wissman S, Albers GW, et al: Recombinant tissue-type plasminogen activator (alteplase) for ischemic stroke 3 to 5 hours after symptom onset. The ATLANTIS study: a randomized controlled trial. Alteplase thrombolysis for acute noninterventional therapy in ischemic stroke. JAMA 1999;282:2019-2026.

10 Yamaguchi T, et al: Alteplase at $0.6 \mathrm{mg} / \mathrm{kg}$ for acute ischemic stroke within 3 hours of onset: Japan Alteplase Clinical Trial (J-ACT). Stroke 2006;37:1810-1815.

-11 Mori E, Minematsu K, Nakagawara J, Yamaguchi T, Sasaki M, Hirano T, et al: Effects of $0.6 \mathrm{mg} / \mathrm{kg}$ intravenous alteplase on vascular and clinical outcomes in middle cerebral artery occlusion. Japan Alteplase Clinical Trial II (J-ACT II). Stroke 2010;41:461-465.

12 Nakagawara J, Minematsu K, Okada Y, Tanahashi N, Nagahiro S, Mori E, et al: Thrombolysis with $0.6 \mathrm{mg} / \mathrm{kg}$ intravenous alteplase for acute ischemic stroke in routine clinical practice. The Japan post-Marketing Alteplase Registration Study (J-MARS). Stroke 2010;41: 1984-1989.

13 Brott TG, Haley EC Jr, Levy DE, Barsan W, Broderick J, Sheppard GL, Spilker J, Kongable GL, Massey S, Reed R, Marler JR: Urgent therapy for stroke. 1. Pilot study of tissue plasmin- ogen activator administered within 90 minutes. Stroke 1992;23:632-640.

14 Haley EC Jr, Levy DE, Brott TG, Sheppard GL, Wong MC, Kongable GL, Torner JC, Marler JR: Urgent therapy for stroke. Part II. Pilot study of tissue plasminogen activator administered 91-180 minutes from onset. Stroke 1992;23:641-645.

15 Khatri P, Broderick JP, Pancioli AM: Risk of thrombolysis-associated intracerebral hemorrhage: the need to compare apples with apples. Stroke 2005;36:1109-1110.

16 Mori E, Yoneda Y, Tabuchi M, Yoshida T, Ohkawa S, Ohsumi Y, Kitano K, Tsutsumi A, Yamadori A: Intravenous recombinant tissue plasminogen activator in acute carotid artery territory stroke. Neurology 1992;42:976-976.

17 Yamaguchi T, Hayakawa T, Kiuchi H: Intravenous tissue plasminogen activator ameliorates the outcome of hyperacute embolic stroke. Cerebrovasc Dis 1993;3:269-272.

18 Yamaguchi T, Hayakawa T, Kiuchi H: Clinical efficacy and safety of intravenous tissue plasminogen activator in acute embolic stroke: a randomized, double-blind, dose comparison study of duteplase; in Yamaguchi T, et al (eds): Thrombolytic Therapy in Acute Ischemic Stroke III. Tokyo, Springer, 1995, pp 223-229.
Low-Dose tPA and Standard-Dose tPA in Acute Ischemic Stroke
Cerebrovasc Dis 2013;36:161-166 DOI: $10.1159 / 000354162$ 
19 Wahlgren N, Ahmed N, Dávalos A, Ford GA, Grond M, Hacke W, Hennerici MG, et al: Thrombolysis with alteplase for acute ischaemic stroke in the Safe Implementation of Thrombolysis in Stroke-Monitoring Study (SITS-MOST): an observational study. Lancet 2007;369:275-282.

20 Chao AC, Hsu HY, Chung CP, Liu CH, Chen $\mathrm{CH}$, Teng MM, et al: Outcomes of thrombolytic therapy for acute ischemic stroke in Chinese patients: the Taiwan Thrombolytic Therapy for Acute Ischemic Stroke (TTTAIS) study. Stroke 2010;41:885-890.

21 Nguyen TH, Truong ATL, Ngo MB, et al: Patients with thrombolysed stroke in Vietnam have an excellent outcome: results from the Vietnam Thrombolysis Registry. Eur J Neurol 2010;17:1188-1192.

22 Chen C-H, Hsieh C-Y, Lai T-B, Chuang M-T, Chen W-L, Sun M-C: Optimal dose for stroke thrombolysis in Asians: low dose may have similar safety and efficacy as standard dose. J Thromb Haemost 2012;10:1270-1275.

-23 Zhou XY, Wanga SS, Collins ML, Davis SM, Yan B: Efficacy and safety of different doses of intravenous tissue plasminogen activator in Chinese patients with ischemic stroke. J Clin Neurosci 2010;17:988-992.
4 Lees KR, Bluhmki E, von Kummer R, Brott TG, Toni D, Grotta JC, Albers GW, Kaste M, Marler JR, Hamilton SA, Tilley BC, Davis SM, Donnan GA, Hacke W, ECASS, ATLANTIS, NINDS and EPITHET rt-PA Study Group, Allen K, Mau J, Meier D, del Zoppo G, De Silva DA, et al: Time to treatment with intravenous alteplase and outcome in stroke: an updated pooled analysis of ECASS, ATLAN TIS, NINDS, and EPITHET trials. Lancet 2010;375:1695-1703.

25 Sharma VK, Tsivgoulis G, Tan JH, Ong BKC, Chan BPL, Teoh HL: Feasibility and safety of intravenous thrombolysis in multiethnic Asian stroke patients in Singapore. J Stroke Cerebrovasc Dis 2010;19:424-430.

26 Pan S-M, Liu J-F, Liu M, Shen S, Li H-J, Dai L-H, Chen X-J: Efficacy and safety of a modified intravenous recombinant tissue plasminogen activator regimen in Chinese patients with acute ischemic stroke. J Stroke Cerebrovasc Dis 2013;22:690-693.

27 Suwanwela NC, Phanthumchinda K, Likitjaroen Y: Thrombolytic therapy in acute ischemic stroke in Asia: the first prospective evaluation. Clin Neurol Neurosurg 2006;108: 549-552.

28 Murata M: Genetic polymorphisms associated with thrombotic disorders in the Japanese population. Fibrinol Proteol 2000;14:155164.

29 Ikram MA, Seshadri S, Bis JC, Fornage M, DeStefano AL, Aulchenko YS, et al: Genomewide association studies of stroke. N Engl J Med 2009;360:1718-1728.
30 Matsushita T, Umeno J, Hirakawa Y, Yonemoto K, Ashikawa K, Amitani H, Ninomiya $\mathrm{T}$, et al: Association study of the polymorphisms on chromosome 12p13 with atherothrombotic stroke in the Japanese population. J Hum Genet 2010;55:473-476.

31 Wong LKS: Global burden of intracranial atherosclerosis. Int J Stroke 2006;1:158-159.

32 Durai Pandian J, Padma V, Vijaya P, Sylaja PN, Jagaralpudi MKM: Stroke and thrombolysis in developing countries. Int J Stroke 2007; 2:17-26.

33 Yoneda Y, Yamamoto S, Hara Y, Ohta K, Matsushita M, Yamamoto D, et al: Post-licensed 1-year experience of systemic thrombolysis with tissue plasminogen activator for ischemic stroke in a Japanese neuro-unit. Clin Neurol Neurosurg 2007;109:567-570.

-34 Toyoda K, Koga M, Naganuma M, et al: Routine use of intravenous low dose recombinant tissue plasminogen activator in Japanese patients: general outcomes and prognostic factors from the SAMURAI Register. Stroke 2009;40:3591-3595.

35 Iso H, Folsom AR, Koike KA, Sato S, Wu KK, Shimamoto T, Iida M, Komachi Y: Antigens of tissue plasminogen activator and plasminogen activator inhibitor 1: correlates in nonsmoking Japanese and Caucasian men and women. Thromb Haemost 1993;70:475. 